\title{
A SUBJETIVIDADE E A EXPERIÊNCIA DO OUTRO: MAURICE MERLEAU-PONTY E EDMUND HUSSERL*
}

Creusa Capalbo

\begin{abstract}
Resumo: A fenomenologia de Merleau-Ponty segue, a seu modo, o pensamento encontrado em Husserl na sua obra inacabada "Krisis". Ele critica a teoria transcendental e o método da redução, propostos por Husserl, por julgar que deve ater-se à filosofia da existência e da subjetividade, em sua condição de ser situado no mundo da vida. O mais importante para o sujeito consiste na busca de sentido para a sua vida e isto, conduzido a seu termo, esclarece-nos sobre o que é a natureza, a história, o mundo e o ser. A analítica existencial de Merleau-Ponty, sobre a experiência do outro e da subjetividade, faz-se a partir do seu ser-no-mundo, isto é, no contexto histórico, social e psicológico. Palavras-chave: Fenomenologia, Subjetividade, Existência, Historicidade, Mundo da Vida.
\end{abstract}

Merleau-Ponty critica Husserl por seu método da variação imaginária e, de modo mais geral, critica a fenomenologia transcendental concebida como ciência eidética das essências. Para Husserl, o acesso à essência pressupõe a experiência originária da percepção, mas é pela livre variação imaginária - que faz variar em pensamento à experiência, para isolar um invariante - que se pode aceder à essência do fenômeno descrito. Se compreendermos isto no sentido de que tal afirmação introduz uma oposição entre fato e essência, oposição entre a indução que pode aceder à essência a partir de casos reais e a eidética que acede à essência a partir de casos imaginários; ou então, no sentido de uma dependência das ciências de fato das ciências eidéticas formais ou materiais, este método não tem razão de ser, pois reserva apenas à imaginação e à filosofia a possibilidade de realizar a variação eidética (Merleau-Ponty, 1964).

Merleau-Ponty afirma que este método eidético ou o logicismo da primeira fase do pensamento de Husserl será abandonado por seu existencialismo do último período. Ele vai reinterpretar o método husserliano e mostrar como o caminho por ele percorrido pode conduzi-lo à compreensão da essência encarnada, da essência concreta, ou a uma nova maneira de conceber a relação matéria e forma.

Com efeito, nas Idéias, Husserl fala do primado da percepção considerada como doação originária, isto é, que pela percepção nós apreendemos o objeto em sua corporeidade. À percepção, como experiência doadora originária, opõe-se a recordação, a imaginação e o juízo, que são exemplos de presentificação. Os atos de presentificação se fundam sobre a percepção e eles são modificações deste modo original.

A investigação fenomenológica, de ordem lógica, em sua dependência da percepção sensível, será o objeto das análises de seus livros Lógica Formal e Transcendental e Experiência e Juízo. A ordem predicativa reenvia-nos à presença

\footnotetext{
* Trabalho apresentado no XIII Encontro Goiano da Abordagem Gestáltica e II Encontro de Fenomenologia do Centro-Oeste, realizado em maio de 2007
} 
do mundo, à ordem ante-predicativa ou pré-reflexiva. Analisar as estruturas da receptividade (do dado passivo) e as estruturas da espontaneidade (da orientação ativa do Ego) marca, em Husserl, a passagem da fenomenologia estática para a fenomenologia genética (Husserl, 1970, p.93). Merleau-Ponty reinterpretara, a partir desta perspectiva genética, o papel da variação eidética para mostrar que ela será uma "imaginação produtiva", situada, ao menos virtualmente, no meu campo perceptivo e assim implicada na minha apreensão geral sobre o mundo. Esta passagem para uma fenomenologia genética supõe também o abandono da filosofia como ciência rigorosa, pois não há mais lugar para um "conhecimento de verdades eternas" conforme queria Husserl em Idéias. ${ }^{1}$

Nas notas de $\boldsymbol{O}$ Visível e o Invisível, Merleau-Ponty indica a possibilidade de uma nova compreensão da variação eidética. A essência que ela nos oferece é a estrutura visível do ser que possui uma dimensão de sentido in-visível. Este visível é o sentido expresso, mas a expressão está ligada à percepção e ao Ser Bruto de onde surge todo sentido. Este invisível é a palavra antes de ser pronunciada, é o silêncio circundante da palavra, é uma expressão primordial. Ele reafirma ainda, nestas notas, que a variação eidética não nos fornece o acesso a uma essência separada ou a uma essência concebida como um "possível lógico", ela nos dá "um invariante estrutural, um ser de intra-estrutura que em última análise só tem seu Erfüllung na Welthesis deste mundo aqui". ${ }^{2}$

É de Husserl que Merleau-Ponty recebe a idéia de que a essência deve ser considerada como possível em relação ao conhecimento da realidade. Em que sentido devemos compreender esta afirmação?

Nós sabemos que a possibilidade, segundo Aristóteles é compreendida, de modo geral, como potência e, às vezes, como contingência. Os racionalistas do século XVIII dirão que os possíveis reais são essenciais dependentes da possibilidade ideal ou lógica. A passagem para a afirmação de que a verdadeira ciência deve ser a do conhecimento destes possíveis ideais far-se-á, a seguir, muito facilmente.

Husserl não quer, precisamente, que se concebam os possíveis neste sentido do racionalismo. Para ele o possível é um "poder-ser" que depende da atividade do sujeito para ser.Éneste sentido que Merleau-Ponty interpreta também o possível, quando escreve: "trata-se duma potência-dum eu posso" (Merleau-Ponty, 1964, p. 278).

Esta essência encarnada, este invariante estrutural, é uma com a estrutura total do ser. A fenomenologia deve, justamente, descrever esta estrutura.

A essência, afirma Merleau-Ponty, não é um campo transcendental separado da existência: ela está no campo fenomenal inerente ao mundo. O Husserl da fase final já havia posto em relevo a ambigüidade da reflexão e a irredutibilidade do

\footnotetext{
${ }^{1}$ O próprio Husserl escreveu na obra "Crise da Ciência e da Humanidade Européia”, no apêndice XXVIII do § 73, p.535: "A filosofia como ciência, como uma ciência séria, rigorosa e apodítica — o sonho acabou".

${ }^{2}$ Nota de fevereiro de 1960. In Le visible et l'invisible, p.289. E ainda em "Le langage indirect et les voix du silence" in Revue Temps Modernes, 7, p. 2.113-2.144; 8, 1952, p.70-94 e republicado in Signes, p. 58-84.
} 
irrefletido, e fundado o conhecimento sob a doxa originária. Ora, a busca do sentido, conduzida a seu termo, esclarece-nos sobre o "que é a Natureza, a História, o Mundo e o Ser" (Merleau-Ponty, 1964, p.146).

A essência não é o dado primeiro, nem a última questão da filosofia. Ela é uma expressão segunda da experiência; somente a experiência originária é fonte de idealizações.

Segundo Husserl, as essências emergem da variação que eu submeto às coisas pela imaginação, a fim de verificar o que poderia modificar sem que a coisa cesse de ser o que ela é nela mesma; ela é o in-variante que permanece após as variações que nós submetemos à coisa. A essência, assim concebida, não é a expressão do Ser, diz Merleau-Ponty, não é o "estilo" da existência do Ser. Ela é antes uma essência, mas que, assim sendo, não existe, pois ela nada mais é do que o resultado duma ideação que se faz no espaço-tempo de existência, a qual tem uma história e é a expressão de nossas experiências. Para Merleau-Ponty, a essência será a expressão da articulação de um sentido interior aos fatos. Essência e fato isolados são abstrações, o que existe é o Ser Bruto, "facticidade e idealidade indivisas" (Merleau-Ponty, 1964, p. 148-149).

Até a Fenomenologia da Percepção a preocupação principal de MerleauPonty foi a de descrever a estrutura do ser humano nas análises que ele fez da percepção, da corporeidade, da sexualidade, da linguagem, da intersubjetividade, do pensamento, da liberdade, da temporalidade.

No prefácio de Sinais escrito em 1960 e no O Visível e o Invisível, sua visão sobre o homem e a filosofia sofre uma certa modificação. A questão principal não é mais a descrição da percepção do mundo, da experiência do corpo próprio ou do homem como presença ao mundo; agora, a questão principal gira em torno da pergunta: como o homem é capaz de constituir sentido no mundo. A primeira resposta consistiu em dizer que o mundo era contingente. À reflexão, uma outra maneira de ver aparece: é o Ser que fala em nós. Se nós falamos do ser, é do Ser Selvagem, indefinível. O projeto de Merleau-Ponty é, agora, de repensar nossa experiência de ser-no-mundo, de saber qual é o sentido de Ser-mundo, do SerCoisa, do Ser imaginário, do Ser homem, a partir da relação solitária, global, do visível e do invisível, do silêncio que nos fala, da ausência e da presença do Ser.

O próprio Merleau-Ponty diz que era preciso conduzir os resultados da Fenomenologia da Percepção à explicitação antológica do Ser Bruto ou Selvagem, pois ele permanecera na descrição fenomenológica ao nível de uma "filosofia da consciência” e não de uma filosofia do ser (Merleau-Ponty, 1964, p.237).

Trata-se, portanto, daqui por diante, de interrogar esta estrutura do Ser Selvagem donde nasce todo o sentido dos entes, e de compreender que a estrutura do Ser é, ao mesmo tempo, visível e invisível.

A pesquisa filosófica de Merleau-Ponty é centrada na análise da existência concreta e na explicitação da experiência humana em sua totalidade. Esta análise é feita através do exame da questão da percepção. Até o fim ele permaneceu fiel ao programa traçado na sua obra Fenomenologia da Percepção: analisar e aprofundar a 
experiência da percepção. Por este caminho, é-se levado até a espessura da coisa e do mundo, na qual se enraíza a razão, não se trata de "colocar a fé perceptiva no lugar da reflexão”, mas sim de compreender que há reenvio de uma a outra; é a "reflexão que se volta para a espessura do mundo para aclará-lo, e que lhe reenvia a sua própria luz". Assim, a reflexão se enraíza no visível e, por este meio, ela nos permite ter acesso ao invisível (Merleau-Ponty, 1964, p. 57).

É do pensamento de Husserl, em sua última fase, que Merleau-Ponty retirará a concepção de que o pensamento está ligado à terra, como o abrigo no arco da ponte, na qual ela se refugia, ou como ao solo no qual ele está enraizado. Assim sendo, o pensamento não está nunca cortado de suas amarras perceptíveis, de suas raízes corporais e sensíveis.

A percepção se apresenta como reencontro entre a subjetividade e as coisas; o percebido se apresenta como aquilo que é e que permanece em seu ser. Assim, há coisas a ver, há um mundo onde vivemos e que se mostra a nós por si mesmo. É no reencontro da subjetividade e do mundo que nasce a percepção. Mas, o percebido que se apresenta em pessoa na evidência da presença, revela também o seu outro lado. Há uma "película de invisível no visível" e o "invisível é a contrapartida secreta do visível, que só nele aparece". Por isto, é que se pode afirmar que a percepção não é um puro ver da presença; isto que a consciência não vê é o seu "punctum caecum", ou seja, aquilo que a faz ver: seu vínculo ao Ser (MerleauPonty, 1964, p.269-302).

O "princípio dos princípios" da fenomenologia de Husserl, a evidência da coisa dada à consciência, a sua doação em pessoa é agora colocado em questão por Merleau-Ponty. Para este, a doutrina que faz da "claridade perfeita a medida de toda verdade” não se dá conta dos dados da ontologia do sensível que nos mostram um tipo da experiência proveniente da "carne do Ser Bruto".

O próprio Husserl havia estabelecido que as investigações sobre a constituição nos reenviam para o plano do pré-reflexivo, ao Lebenswelt (ou mundo da vida) e às questões da gênese passiva. No entanto, conforme diz Paul Ricoeur (1950, p.III), “a fenomenologia husserliana não pode ir até ao fim no fracasso da consciência; ela permanece no círculo das correlações entre a 'noesis' e os 'noemas"'. Para romper este círculo é necessário deslocar a questão da "constituição" para dar a da "instituição" e é isto, a nosso ver, que Merleau-Ponty realiza. A modificação da questão, processada por este autor, faz com que se dê, em conseqüência, a transformação de alguns conceitos da fenomenologia.

Merleau-Ponty aprofunda a sua interrogação sobre a percepção originária e vai encontrar a "carne do mundo" como seu fundamento, ou seja, o "Servisto", o "sensível", que não se confunde com aquele que sente. Ele prossegue a sua investigação sobre este caminho da ontologia do sensível, onde todos os visíveis se encontram trazidos ao horizonte total do Ser, e a região "selvagem do Ser Bruto". Desta forma, Merleau-Ponty é levado a aprofundar o "princípio bárbaro" da filosofia, ou aquilo que sempre resistiu à fenomenologia: os domínios do Ser Selvagem e da natureza. 
Todas as dimensões existentes são erguidas a partir do Ser Bruto, do "Ser englobante-englobado". Visando explicitar este poder de "pregnância" ou de "surgimento de uma forma", Merleau-Ponty introduz a noção de Historicidade Vertical. Esta opera como um princípio, em virtude do qual há "surgimento imotivado", há uma Urstiftung (instauração originária) e não uma subsunção. Vêse, assim, que a historicidade está estreitamente ligada à instituição, ou que instituir é específico à historicidade. É graças ao conceito de instituição que é possível apreender uma certa estabilidade no movimento do Ser, na natureza, na história e no ser do homem. É graças ao conceito de instituição que se pode apreender a "espontaneidade cumulativa" e a "sedimentação ativa”. A história explicita o movimento institucional no seio de uma "história cumulativa" e de uma "espontaneidade ensinante" (Merleau-Ponty, 1960, p.75-121).

Merleau-Ponty quis estudar a instituição efetiva no domínio da natureza, da vida e do homem. A cada tipo de instituição correspondente, um tipo de historicidade, onde se dará a estabilidade no movimento, a sedimentação ativa e a espontaneidade cumulativa.

O tema da historicidade, tal como ele se apresenta à análise dos escritos de Merleau-Ponty, se situa na questão da passagem de uma filosofia do Erlebnis (da experiência vivida) ou de uma filosofia da consciência, para a filosofia do Ser Selvagem, onde a noção de Urstiftung (de instauração originária) é central - é a esta que se chama de Historicidade Vertical.

Por ocasião do centenário de nascimento de Edmund Husserl foi publicada uma obra em sua homenagem. Nela Merleau-Ponty escreve que no conjunto das obras de Husserl há um impensado, em suas entrelinhas, que precisa ser desvelado. Far-se-ia, deste modo, que a ausência de Husserl devida à sua morte, tornar-se-ia presença pela sua obra, por meio da qual ela nos oferece matéria para pensar.

Ao reconhecer que seu pensamento foi influenciado por Husserl, MerleauPonty nos diz que não pretende fazer uma exegese de seu pensamento expresso objetivamente em seus escritos. O que ele quer é se colocar na trilha deste impensado procurando explicitá-lo. Assim, tal como Husserl, a leitura dos textos que nos são oferecidos pela história da filosofia visa sublinhar a intenção dos filósofos. Com efeito, foi assim que Husserl procedeu na análise do Cogito Cartesiano, da história da ciência, do empirismo inglês, da filosofia transcendental de Kant. O que MerleauPonty faz agora é aplicar este projeto à própria fenomenologia de Husserl; às noções de comportamento e de forma utilizadas pela filosofia contemporânea; ao conceito de história e de dialética presentes no pensamento de Hegel, Marx ou Luckács; à noção de linguagem na lingüística de Saussure ou de Martinet; à noção de inteligência em Piaget; aos temas do inconsciente e da técnica psicanalítica de Sigmund Freud, M. Klein, J. Lacan, A. Freud; à noção de estrutura na antropologia de Mauss ou de Lévi-Strauss.

É preciso descrever os atos da consciência e os diversos modos pelos quais nós temos acesso às coisas nelas mesmas, ou seja, as modalidades do aparecer das coisas que são vividas por nós. É pela descrição que se pode ver a 
estrutura essencial do objeto. A essência ou o "eidos" é um invariante que perdura e se mantém "o mesmo" após a série de variações imaginárias a que nós submeteremos o objeto. A fenomenologia é uma ciência eidética descritiva das essências do vivido. Ela não será uma ciência exata, mas será, isto sim, uma ciência rigorosa. ${ }^{3}$

Esta fenomenologia concebida como uma filosofia universal, que busca uma compreensão e explicitação do mundo em sua totalidade, e que quer ser uma ciência eidética universal, tal como Husserl já anunciava em seu curso de 1907, encontra a sua primeira expressão literária nas "Idéias I", publicada em 1913. A partir desta data há uma divisão entre os fenomenólogos. Aqueles que adotam a filosofia transcendental e genética, pouco numerosos, e aqueles que se vinculam a uma fenomenologia eidética e puramente descritiva, os mais numerosos. É neste grupo que se coloca Merleau-Ponty.

O projeto Husserliano de elaborar uma fenomenologia pura consistia em realizar a análise reflexiva dos fenômenos, visando apreender sua essência pela intuição eidética, graças ao método de variação eidética. Nesta época, Husserl estava preocupado em explicitar os atos intencionais e seus correlatos noemáticos (seus conteúdos). No entanto, a análise do fenômeno intencional era feita do ponto de vista estático e por isto ele não se sentia obrigado em justificar a gênese deste fenômeno.

Van Breda (1962) diz que Husserl só se defronta com esta questão por volta de 1920, quando ele então elabora o seu método sob o nome de análise intencional genética, e que isto foi notado por poucos autores que seguiam a fenomenologia. Escreve Van Breda: "Para Husserl, a descrição do dado estático sempre foi e continuará sendo tão-somente uma forma de entrada no assunto, que lhe permitirá abrir o caminho para a redescoberta, e daí para a explicação de sua gênese, ou seja, de sua "história intencional". ${ }^{4}$

Nós sabemos que para Husserl a fenomenologia transcendental está ligada à problemática da redução transcendental como um caminho para se chegar aos dados da consciência; a origem destes dados se encontra na sua constituição pelo ego transcendental.

A tarefa da fenomenologia genética será a de elucidar de que modo a subjetividade operante é responsável pela constituição de sentidos sedimentados na história, pela constituição da lógica formal e da ciência exata. Ela nos reenvia

\footnotetext{
${ }^{3}$ Husserl entende por objeto tudo que é resultado da atividade intencional do sujeito. Ele é a primeira categoria da ontologia formal. As formas dos objetos são as relações, os números, os objetos situados no tempo, o todo, o gênero, a espécie, as propriedades. Por objeto não se entende apenas os que estão no mundo factual, mas também os objetos possíveis ou ideais. Ver Idées directrices, pour une phénoménologie, 1950, pp. 235-241.

${ }^{4}$ Van Breda, H.L. L'itinéraire husserlien de la phénoménologie pure à la phénoménologie transcendentale, p. 15. Este artigo é inédito. Ele foi objeto de uma conferência que o professor proferiu em Paris a convite da "Sociedade Francesa de Filosofia" e que amavelmente colocou a nossa disposição o seu texto escrito.
} 
também à questão da fundamentação dos juízos na percepção externa, no papel da percepção do corpo e das estruturas da receptividade do ego.

Husserl, porém, jamais abandonou a idéia de que a fenomenologia, mesmo no seu esforço genético, deixe de lado a análise dos dados intencionais da consciência sob o prisma da sua significação. A sua principal preocupação, ao longo de sua vida, foi a de querer saber como as coisas aparecem para nós, de que modo podemos restabelecer o contato "com as coisas nelas mesmas", e como o sentido das coisas se constitui em nós. No entanto, adverte-nos, não devemos afirmar que se uma coisa aparece a uma consciência a afirmativa de sua existência seja necessária. Na descrição deste "aparecer" há sempre uma visada da existência, mas não é necessário efetuá-la. Para realizar este programa é preciso fazer a "Epoché" de todos os nossos conhecimentos científicos ou filosóficos, isto é, suspender os nossos juízos a propósito da ingênua aceitação da transcendência, praticada pela subjetividade mundana, e pelos ensinamentos que nos são transmitidos pela cultura ou pela história em relação às coisas que desejamos conhecer. Antes da "Epoché" (da suspensão ou redução destes juízos) tudo nos parece certo. Pela "Epoché" começamos a duvidar de nossas crenças ou das nossas aquisições sedimentadas pela tradição e pela cultura. Este ponto de partida é o mesmo que foi empreendido por Descartes e que será levado a uma direção ainda mais radical por Husserl (1950, p.62-97).

Comentando Husserl sobre este assunto, Paul Ricoeur diz que a Epoché difere da dúvida cartesiana porque ela é "um ato de suspensão e não de negação, é um ato de conjectura, de suposição calculada, de dúvida". Aquilo que é posto entre parênteses não é anulado, ao contrário, ele é deixado intacto; ele é posto "fora de circuito" e sobre ele se interdiz de fazer um juízo sobre a sua existência espaço-temporal. Colocar "fora de circuito" é um ato que se faz em diferentes estágios os quais Husserl chama de "redução progressiva ou redução fenomenológica” (Ricouer, 1950).

O aspecto positivo da Epoché é a abertura a que ela nos conduz em direção ao campo transcendental da subjetividade e dos fenômenos. O mundo se torna um “cogitatum", objeto da experiência do ego transcendental, um fenômeno para a consciência. A tarefa da fenomenologia será a de mostrar como, graças à Epoché, nós podemos obter uma "esfera nova e infinita de existência que atinge uma nova experiência, a saber, a experiência transcendental” (Husserl, 1957, p. 23-43).

O ego se torna, pois, um "campo possível de investigação". Na análise de sua vida vê-se que ele sempre visa algo, e que o traz em seu seio enquanto visado (ou seja, enquanto objeto de uma intenção), enquanto seu "cogitatum" específico. As descrições deste algo visado se chamam de noemáticos e aquelas concernentes às modalidades do visar do Cogito chamam-se de noéticas. As cogitações são dadas com o ego. A estrutura típica a que se chega se expressa, para Husserl, como "egocogito-cogitatum”.

É pela redução fenomenológica que temos acesso ao objeto puro. Ser um objeto implica em ter um sentido para um sujeito, em ser visado pelo ego. Esta 
visada nos indica a intenção que nos dá o fenômeno enquanto intencional de uma noesis. ${ }^{5}$ A questão que Husserl coloca é justamente esta, ou seja, a de saber como estes objetos se constituem para a consciência pura, ou ainda, como o núcleo noemático é dado à consciência, como nós constituímos o sentido deste noema, e como o sentido se reporta ao objeto?

A constituição do objeto "se refere, em primeiro lugar, a uma consciência individual possível por essência, e em seguida, a uma consciência comunitária possível (...); é graças a esta pluralidade de consciências que uma coisa pode ser dada e identificada de modo intersubjetivo enquanto realidade objetiva idêntica”. A constituição do objeto é a função operativa primordial do ego transcendental, entendido, nas Meditações Cartesianas, como um ego monádico que deveria explicar a sua própria Constituição. ${ }^{6}$ É aqui que se colocam os problemas da fenomenologia genética, sob a forma da investigação da estrutura genética do ego e onde o tempo aparece como "forma universal de toda gênese egológica". No entanto, na $5^{\text {a }}$ meditação, Husserl insiste sobre o fato de que o domínio transcendental pertence à "intersubjetividade monádica” (Husserl, 1964, p.324).

A constituição genética pode ser ativa e passiva. A gênese ativa realiza atos específicos do ego. Ela pressupõe uma síntese da experiência passiva que recebe os dados como "todos prontos". Em sua obra "Experiência e Juízo", Husserl explica que o "dado já-aî" é o mundo, e que este é "o pré-dado universal passivo preliminar a toda atividade do juízo", é o Lebenswelt (o "mundo-da-vida”) como mundo da experiência originária que precede, ou, para ser mais preciso, que é o fundamento de todo pensamento científico e filosófico. A existência é o resultado da constituição de um sentido no seio do ego. Assim, a natureza, a cultura, a ciência são a explicitação de um sentido constituído pelo ego-transcendental intermonádico (Husserl, 1970, p.6-19).

Por meio da constituição genética Husserl quer traçar a gênese intencional de uma significação a fim de retornar à sua origem fundante. Na teoria dos juízos de evidência, ele escreve, por exemplo, que é preciso ir-se das "evidências predicativas até a evidência não-predicativa que se chama experiência”. Esta experiência nada mais é que a consciência de estar em presença das coisas tais como são nelas mesmas (Husserl, 1957, p.283).

Assim, o retorno às coisas torna-se retorno às experiências nas quais as coisas se constituem pela função primordial do ego transcendental. Esse retorno é o da experiência pré-reflexiva do mundo da vida, ou o retorno a uma subjetividade operante que está velada "por seu vestimento de idéias". É, pois, da subjetividade transcendental que estamos tratando ao falar de retorno ao mundo da vida ou das

\footnotetext{
${ }^{5}$ Husserl diz que os fenômenos da fenomenologia caracterizam-se como irreais, ou seja, são puras e colocadas ao nível dos vividos da consciência, e opõem-se aos fenômenos da ciência que são reais ○ ou inseridos no mundo real.

a $\quad{ }^{6}$ Até a obra Krisis o ego transcendental era considerado como a priori universal de toda Constituição. A partir desta obra encontra-se no $§ 36$ outro a priori: o mundo da vida - Lebenswelt.
} 
operações subjetivas que engendram o mundo da vida. É na passividade que se encontra o fundamento último de toda experiência e ela pressupõe que o "dado preliminar seja dado numa experiência sensível imediata".

Na obra "Consciência íntima do tempo", Husserl distingue a aparição perceptiva da aparição imaginativa, pois a matéria da percepção é feita de impressões sensoriais e a da imaginação de "fantasmas". Esta teoria das impressões sensoriais não foi abandonada por Husserl em suas obras ulteriores. Assim, por exemplo, nas "Meditações Cartesianas" ele distingue as sínteses passivas que se faz por associação (tal como a percepção), das sínteses ativas, tais como o juízo, a ação, a volição, as quais pressupõem uma passividade que recebe o objeto.

A síntese passiva fornece a matéria à síntese e esta, por sua vez, é descrita por Husserl como uma síntese da forma. Trata-se da aplicação da teoria da matéria sensível e da forma intencional, da dualidade "hylémorphe", indispensável à constituição da percepção e da imaginação. Husserl afirma, ainda, a distinção entre sensação e percepção quando ele escreve que a "hylé" da percepção é a sensação. A "hylé" é reafirmada como necessária para a constituição da imaginação, do tempo e do ego puro. ${ }^{7}$

A doutrina da redução e da fenomenologia transcendental é ainda afirmada por Husserl em 1937 na obra Krisis. É preciso realizar a “époché” da ciência objetiva para poder liberar o mundo da vida, e permitir que este se revele como "o reino dos fenômenos subjetivos que permaneceram anônimos".

Deve-se compreender por Lebenswelt o mundo espaço-temporal das coisas experimentais ou suscetíveis de serem experimentadas por nós na nossa vida précientífica ou ante-predicativa.

Por coisa deve-se compreender os objetos de natureza física, vegetal e animal e neste o próprio homem com tudo quanto ele produz. O mundo é visto como horizonte de nossas experiências atuais ou possíveis das coisas. Ele é a totalidade das coisas.

A finalidade de Husserl será a de descrever este mundo, e de fazer uma ontologia. Este mundo tem uma estrutura geral, a saber: a espaço-temporalidade, a corporeidade e a estrutura categorial. Ele nos adverte para não confundirmos o espaço vivido da Lebenswelt com o espaço geométrico, o tempo vivido com o tempo objetivo da física, o corpo vivido ou o corpo próprio com o corpo da física ou da biologia (que se escreve em alemão Korper), nem a estrutura categorial vivida com a idealização teórica da língua constituída (Husserl, 1961, p.141-228).

O papel da "époché" é também apresentado como necessário para nos liberar da perspectiva da atitude natural face ao Lebenswelt e ao nível transcendental. O filósofo descobre então que o mundo é correlato da consciência, da subjetividade.

\footnotetext{
${ }^{7}$ A Teoria Husserliana das sínteses passivas é muito complexa e não é nosso objetivo analisá-la. Lembrese apenas o seguinte: em Meditações Cartesianas de Husserl, § 38 as presentificações são colocadas entre as sínteses passivas; em Experiência e Juízo, § 15, ele escreve que nos sentimentos há receptividade e os dados sensíveis são qualificados como passividade originária no nível o mais profundo da constituição. Finalmente, em Krisis, apêndice 6, ele afirma que a imaginação é também receptiva.
} 
O mundo se torna fenômeno transcendental pela experiência da subjetividade transcendental: o caminho de acesso à redução é o "mundo já dado", a vida mundana natural, ou seja, os dados sensoriais.

Graças à redução, toda objetividade se torna correlata da intenção subjetiva, fenômeno para o ego transcendental.

Ainda aqui a constituição é definida como constituição de um sentido preso à temporalização, visto ser o mundo espaço-temporal e o seu sentido estar nele inserido.

Neste itinerário, rapidamente traçado, da fenomenologia de Husserl, vê-se que o seu projeto de uma filosofia transcendental não foi abandonado. $\mathrm{Na}$ fenomenologia estática o termo transcendental é empregado para indicar a problemática dos vividos intencionais considerados na sua essência eidética que pertence à consciência pura. Na Krisis, ele nos explica que o uso que ele faz do termo transcendental é mais amplo do que o de Kant, e que, por este termo, ele quer indicar o retorno à fonte última e primeira de todo conhecimento: o ego e seu relacionamento com a sua vida consciente e com o mundo. Ele o designa de ego puro ou de experiência do eu puro (Husserl, 1961, § 26).

A questão da redução é, pois, um tema capital do pensamento de Husserl. Graças a ele, a fenomenologia pode partir da análise do que já está constituído no plano da ciência, da filosofia, da cultura, para chegar à subjetividade absoluta que os constitui.

A redução fenomenológica como método de suspensão dos juízos pela époché significa, na verdade, que se coloca entre parênteses a atitude natural, a crença na existência do mundo. O resultado desta époché é a estrutura "ego-cogitocogitatum", no qual o mundo se torna fenômeno para a consciência. Desta forma ése mergulhado na filosofia da subjetividade que nos permite compreender o mundo como correlato da subjetividade absoluta, e que, para Husserl, não deve ser entendida como "solus ípse", mas como intersubjetividade.

O método de Husserl é o de uma fenomenologia reflexiva e a atitude do fenomenólogo é o de um "espectador desinteressado". Mas esta atitude não é puramente passiva; ela é, também, capaz de realizar sínteses ativas conforme já dissemos.

Os conceitos de redução e o de constituição são muito importantes para o conjunto da teoria de Husserl, embora sejam termos desprovidos de uma significação precisa. ${ }^{8}$

Eugen Fink nos propõe a distinção entre conceitos temáticos e operatórios para compreender os conceitos utilizados por Husserl. Os primeiros exprimem os conceitos utilizados para compreender uma certa realidade que perdura problemática. Ele nos dá como exemplos destes conceitos os da mônoda em

\footnotetext{
${ }^{8}$ Lauer, Q. Phénoménologie de Husserl. Essai sur la genèse de l'intentionalité, p. 22. Este autor assinala que o significado de "preenchimento" não está definido com clareza na obra de Husserl, e que o seu sentido se obtém do uso que ele faz daquele conceito. Observações similares nós encontramos no livro Cahiers de Royaumont-Husserl, feitos por Roman Ingarden e Eugen Fink.
} 
Leibniz, da "dynamis" e "energeia" em Aristóteles e subjetividade transcendental no próprio Husserl.

Por conceitos operatórios é preciso compreender aqueles que são utilizados pelo filósofo, mas que não se tornaram objetos expressos de reflexão ou temas; eles funcionam como "força clarificante de seu pensamento". Eles são o "medium" que permite ver sem ser visto. Os conceitos de "époché" e de "constituição", embora a tentativa de tematizá-los feita por Husserl, permanecem operatórios, pois não são explícitos completamente; eles abordam problemas que permaneceram abertos à pesquisa filosófica. E, ainda, E. Fink quem nos diz que a constituição pode se compreender como produção de sentido dos objetos, como atividade da subjetividade transcendental, como colocação em ordem de nossas representações das coisas. Ela é diferente quando se aplica a constituição das coisas ou a dos outros sujeitos.

Roman Ingarden é da mesma opinião quando escreve que o termo "constituição de objeto" é utilizado por Husserl para designar a determinação intencional do sentido de objeto por uma diversidade de aparências e das menções intencionais do ato, e também para designar o processo pelo qual nós chegamos ao sentido invariante de objeto. No mesmo artigo ele acrescenta uma interpretação da constituição: aquela que busca os dados últimos e originários que já estão em conexão com as "últimas unidades da experiência vivida, os quais se constituem na consciência originária constituinte do tempo", da qual se pode alcançar a constituição dos níveis superiores tais como o dos objetos ideais da lógica (Ingarden, 1959, p.242-264).

Há, portanto, na constituição um lugar necessário para a sensibilidade, para os "dados últimos" concebidos como dados hiléticos vinculados à consciência do tempo.

O presente, o passado e o futuro são constituídos pela percepção, pela retenção e pela proteção (enquanto impressão original, a percepção permite o surgimento do presente contínuo).

A elucidação desta experiência originária permitirá mostrar como se elevam as formas superiores a partir das formas inferiores. É a fenomenologia do mundo da experiência que se inaugura, diz Biemel, e que quer mostrar, em última instância, a constituição da ciência e da cultura, bem como as "operações constitutivas que tornam possível o mundo da vida” (Biemel, 1959, p.51).

Toda pesquisa constitutiva nos faz remontar do constituído à constituição, nos faz ver "a história da constituição" ou a gênese do sentido, conduzir-nos até a subjetividade transcendental como fundamento último da constituição. A tarefa da fenomenologia será, justamente, a de estudar esta subjetividade constituinte e de tematizá-la. No processo genético, o primeiro nível denominado por Husserl de "gênese passiva" caracteriza-se pela ausência da predicação "ele é pura sensação disto que está imediatamente presente”. É somente pela gênese ativa que a significação e os juízos serão constituídos.

Segundo a interpretação de Sokolowski, o pensamento genético de Husserl não permitirá mais conceber a matéria e a forma, os "data" sensíveis (hylé) e a 
forma (noesis), como dois elementos distintos; eles são unidos e têm a sua origem no fluxo temporal da consciência e todos dois são dados intencionais. A idéia defendida por Husserl em suas obras "Investigações Lógicas" e "Idéias I", segundo a qual a hylé não é intencional, será abandonada a partir da fenomenologia genética (Sokolowski, 1970, p.211).

A sensação pura, no entanto, é ainda mais mantida como primeiro passo para a consciência ante-predicativa na fenomenologia genética; ela é o material necessário para a constituição dos atos da consciência. O que não se deve mais é pensar que a sensação se encontra fora do campo intencional da consciência.

Nós podemos perguntar ainda se esta sensação não pode ser compreendida como matéria intencional ou com as "data" de sensação tal como Husserl explica em "Idéias I". Com efeito, os dados sensoriais, os "data" hiléticos são simples materiais e não dados intencionais. Mas, os vividos por eles constituídos são intencionais, pois fundidos à intenção eles recebem um sentido. Podemos assim compreender porque Manuela Saraiva observa, com justeza, que "a precisão do pensamento (de Husserl) leva consigo a certas alterações e precisões de terminologia". Assim, os conteúdos representantes (ou conteúdos primários) tornam-se a "hylé" sensual os "data" hiléticos ou materiais, a matéria sensual ou sensível, ou, simplesmente, a matéria (Stoff) ou "hylé". Husserl designa o elemento intencional de "morphé" (forma) intencional ou simplesmente forma (Form) e propõe a designação genérica de momento noético ou noesis (Saraiva, 1970, p.35).

Este longo texto que acabamos de citar nos faz ver que, quando a "hylé" sensual está fundida à forma, há constituição de um objeto intencional e que, neste contexto, a matéria intencional indica a referência objetiva a qual se vincula a intencionalidade de um ato.

Sabemos que o uso do termo sensação é ambíguo nas obras de Husserl. Ele designa, por este termo, tanto os "dados sensoriais" que ainda não foram informados pela visada intencional, quanto o conteúdo imanente do ato perceptivo. A interpretação de Manuela Saraiva é a seguinte: o termo sensação nos indica a "co-naturalidade essencial" entre "a sensação vivida e o ato de perceber". E é por isto que o "conteúdo de sensação, uma vez integrado ao ato perceptivo" torna-se um dado imanente intencional. O conteúdo da sensação torna-se a "hylé" da percepção desde que ela seja animada e informada por uma experiência perceptiva (Saraiva, 1970, p.137-140).

A afirmativa de Sokolowski é, no fundo, a mesma de P. Ricoeur na nota por este escrita no § 85 das "Idéias I", onde se lê: o estudo da "hylé" sobressai ao da constituição dos objetos na consciência, enquanto a intencionalidade o anima. A hilética atrai a noética como a matéria a forma. Mas, em um sentido mais profundo, a "hylé" se aproxima da questão da constituição do tempo e da constituição originária do eu (Urkonstitution): é o fluxo de perspectiva que dá sua duração imanente à visada de um objeto.

É por isto que E. Fink salienta que, se não se vai até a constituição da

이 "hylé" e é desta a constituição do tempo e do ego puro, a constituição da coisa não adquire o seu sentido radical, ou seja, o de ser "criador". 
É na constituição da temporalidade que se apresenta a unidade original do dado sensual e da intenção, e a partir daí poder-se-á dizer que não há mais "hylé" que não seja intencional.

Esta é a problemática que está presente na obra de Husserl: a temporalidade original como temporalidade da impressão originária (Urimpression), como o caráter do "agora" vivente do vivido, o fluxo constituído do tempo como subjetividade absoluta intemporal ou a originalidade da consciência como "Fiat" (Husserl, 1964, p. 99).

A respeito do problema da interpretação da constituição, é preciso ainda observar que certos autores não aceitam que a atividade da subjetividade seja apenas condição de emergência do sentido. Eles afirmam que ela á criadora de sentido (Fink, 1952, p.139).

Maurice Merleau-Ponty teve acesso aos inéditos de Husserl em abril de 1939. Estes inéditos, até hoje conservados nos "Arquivos Husserl” em Louvain, na Bélgica, eram então dirigidos pelo padre franciscano Van Breda. Nestes arquivos Merleau-Ponty consultou as partes ainda não publicadas naquela data da Krisis, das Ideen II e o manuscrito $D 17$ sobre a "Constituição primordial”, ou seja, sobre a gênese intencional da consciência das coisas (Van Breda, 1962, p. 410-430).

Em 1942, Van Breda lhe enviou um exemplar de sua tese de doutorado defendida em Louvain, em 1941, intitulada "A redução fenomenológica na última filosofia de Husserl”. Nesta fase, o autor citava numerosos inéditos de Husserl assim como um apêndice que remetia aos inéditos sobre a Constituição do Mundo (§ 38 e 53 de Krisis). Merleau-Ponty consultou, ainda em 1939, a $6^{a}$ Meditação Cartesiana de Husserl, graças a G. Berger. Em 1944, ele teve à sua disposição, em Paris, a $3^{\mathrm{a}}$ parte da Krisis, a edição alemã das Meditações Cartesianas, os inéditos sobre A Idéia da Fenomenologia, e 870 páginas do grupo $C$ que tratavam do problema da temporalidade.

Vemos, portanto, que Merleau-Ponty já estava em contato com a perspectiva da fenomenologia genética, a respeito da qual falam estes inéditos, à época de suas investigações sobre a Estrutura do Comportamento e a Fenomenologia da Percepção.

Segundo ele, a problemática da redução é uma questão sobre a qual Husserl se debruçou durante toda sua vida, e ela "ocupa um lugar importante nos inéditos". A redução faz-nos voltar à problemática da consciência transcendental e permite definir a fenomenologia como uma filosofia do sentido. Vemos, entretanto, que para Husserl, o sentido não pode ser entendido como um sentido "para mim" apenas. Ele deve ser comunicado e compreendido na sua verdade por mim e pelos outros. Ora, como é possível que um sentido possa ser afirmado e ser conhecido por mim e pelos outros?

Para Husserl, o outro é um problema e a solução que ele encontra na época da Krisis passa pela análise da corporeidade. É por seu corpo que o outro me aparece e é por meu corpo que eu me mostro a ele. Compreende-se, então, porque, nesta ocasião, o primado da percepção será afirmado por Husserl e que será de lá que partirá Merleau-Ponty. 
A primeira experiência do Lebenswelt é uma experiência perceptiva, realizada pelos atos do sujeito no meio ambiente que o envolve, em suas modificações de espaço e em suas modificações de presença ou de temporalidade. Estas experiências são corporais.

Deve-se evitar, entretanto, a confusão entre o corpo perceptivo da ciência, que Husserl chama Körper, com o meu corpo ou o corpo próprio, denominado Leib. É esse último que o fenomenólogo deverá examinar. Aliás, Husserl dá-nos alguns exemplos mostrando que, na percepção corporal, intimamente ligada ao tempo, não devemos confundir os fenômenos cinestésicos, estudados pela ciência, com aqueles que são realizados pelo corpo próprio. É por intermédio deste que eu me percebo no mundo; mas eu sou mais que este corpo próprio, pois sou também um corpo que vive como Körper, isto é, um corpo extenso como coisa entre outras coisas; entretanto, este corpo coisa deve ser afastado da análise fenomenológica se quisermos chegar ao sujeito do corpo (Leib) e não deixar que o sujeito fique reduzido ao estado de objeto (Körper), estudado pela bioquímica, pela biofísica ou pela psico-fisiologia.

Esta descoberta que eu faço de minha inserção no mundo, de minha "relação com o mundo", é o que Merleau-Ponty chama redução. É preciso esta “cumplicidade" de ser-no-mundo para ver melhor, para deixar aparecer a estrutura fundamental do mundo que está recoberta por causa desta proximidade; é preciso afastar-se, tomar distância, para se aperceber do mundo, de si mesmo e dos outros. Merleau-Ponty retoma de E. Fink a interpretação da redução como uma "admiração" do mundo.

Nós sabemos que a admiração é a atitude que inaugura a filosofia, porque ela nos revela que o fato primitivo e primordial, que é o fundamento da existência, é esta relação de intencionalidade operante, expressa pela nossa experiência de estar-no-mundo anterior a toda reflexão. Esta experiência põe-nos em presença virtual do ser que nos permitirá ver e conhecer, a partir deste contato intrínseco com o concreto sensível da unidade "mundo". Esta experiência permite, ainda, que reconheça-mo-nos como abertos ao ser englobante, como visada do mundo, como relação ativa ao outro.

Nesta experiência existencial concreta de ser-no-mundo, a presença virtual do ser permite que vejamos que o ser não está separado da intenção, isto é, de seu sentido. É por isto que não podemos separar a essência da existência e, por isto também, a reflexão é entendida como uma reconquista desta unidade do concreto, e da unidade do ser englobante.

Graças ao nosso afastamento, percebemos as coisas nelas-mesmas, antes da reflexão; deixamos o mundo aparecer tal qual ele é dado nesta experiência vivida pré-objetiva e originária. Graças ao retorno ao originário, Merleau-Ponty será levado às investigações ontológicas de "O Visível e o Invisível".

Numa nota da Estrutura do Comportamento, ele diz que, para voltar à experiência originária da percepção, é preciso realizar a redução fenomenológica, isto é, suspender os juízos da percepção obtidos pela ciência ou pelas teorias to filosóficas, deixar estes “conhecimentos" sobre a percepção para retornar ao vivido da experiência perceptiva do mundo da vida que se dá por perfis. 
Não é preciso entender o ato de conhecer a estrutura do mundo da vida, como faz Husserl em muitos de seus escritos; o conhecimento da coisa mesma, por perfis, faz-se pelo sentido que se oferece à consciência perceptiva. Algumas páginas adiante, Merleau-Ponty afirma que o mais importante, quando se fala de Gestalt, "não é a idéia de significação, mas a de estrutura, a junção de uma idéia e de uma existência indiscerníveis, o arranjo contingente pelo qual os materiais se colocam diante de nós com sentido, a inteligibilidade no estado nascente". Trata-se claramente da perspectiva genética da fenomenologia do último período da filosofia de Husserl. Estas estruturas pertencem à ordem da existência e não à ordem das significações. O problema consiste em compreender como se faz a relação destes perfis com a unidade das coisas que eles apresentam. Este proato que nos faz conhecer as existências, proposto no final da Estrutura do Comportamento, será o tema da Fenomenologia da Percepção (Merleau-Ponty, 1963, p.213-241). Será nesta obra, com efeito, que nós apreendemos melhor a interpretação pessoal da fenomenologia para Merleau-Ponty. Analisaremos, então, sua maneira própria de por em tema os "conceitos operatórios" da fenomenologia de Husserl, a saber: constituição, époché, fenômeno, transcendental, intencionalidade, cogito.

Na Estrutura do Comportamento a redução fenomenológica consiste em fazermos retornar à experiência originária da percepção do mundo da vida. Na análise desta experiência, consideramos separadamente a experiência nela mesma, a experiência perceptiva, e o "Sujeito" ou "objeto" da experiência. Entretanto, Merleau-Ponty não quer decompor a experiência, mas, ao contrário, quer compreendê-la na sua unidade, na sua totalidade nascente. Ele não quer reduzir a experiência do "ser-no-mundo" à "significação mundo", em uma forma de interpretação idealista da redução fenomenológica. Esta coloca-nos no centro da existência e a redução eidética de Husserl é apenas o meio, por ele utilizado, para conhecer a facticidade de nossa existência. Esta experiência original "é a experiência pura e, por assim dizer, ainda muda, que é preciso trazer à expressão pura de seu próprio sentido" (Merleau-Ponty, 1945, p.VI).

Merleau-Ponty quer mostrar, deste modo, que o ato de significar é derivado na ordem genética, e que ele está em relação com esta experiência muda, silenciosa, que envolve todos os sentidos e que os transcende. A filosofia do sentido não é originária. É preciso voltar à filosofia do silêncio. É a esta presença que nos fala pelo e no silêncio que devemos retornar. O ver originário não é o da percepção em ato, mas sim aquele que vê no silêncio do Ser, de onde jorra a palavra e a visão que nos permite escutar e ver aparecer o mundo existente.

Se no prefácio, escrito posteriormente a pedido de Emile Bréhier, MerleauPonty procura restabelecer o valor da redução eidética, o mesmo não será feito nos capítulos que se seguem da Fenomenologia da Percepção. Ele nega, na verdade, que a redução transcendental seja ao mesmo tempo uma redução eidética, se a interpretamos como "visão de essências" separadas da existência, como no idealismo transcendental. Esta dificuldade é sublinhada ainda quando, após a conferência do professor A. De Waelhens, por ocasião do terceiro encontro filosófico de 
Royaumont, no debate que se seguiu, Merleau-Ponty reafirma que se a redução deve ser inicialmente eidética, ela não poderá jamais juntar-se à experiência efetiva, e que Husserl, para evitar esta dificuldade, concebeu a possibilidade da redução transcendental sem passar pela redução eidética. Nestes dois casos, Merleau-Ponty assinala que a dificuldade é a mesma, a saber, o reconhecimento feito por Husserl da resistência que o irrefletido oferece à reflexão, apesar do irrefletido ser compreendido pela reflexão, isto é, o irrefletido é descrito pela reflexão, embora esta "brote" do irrefletido (De Waelhens, 1959, p. 157-159).

Se na Fenomenologia da Percepção ele inclinou-se a dar à redução eidética o ideal ou a "ambição de igualar a reflexão à vida irrefletida da consciência”, cremos que tal inclinação foi abandonada em O Visível e o Invisível, e até mesmo no prefácio de Sinais. Não há mais paralelismo, ou "duas ordens complexas", entre reflexão e irrefletido, entre a essência e o fato, entre linguagem e pensamento; o que há é “intercepção de uma pela outra” ou “acoplamento”. Lemos, já em 1951, (MerleauPonty, 1960, p.25-128), esta mesma idéia, quando diz que o paralelismo de Husserl entre psicologia e fenomenologia, "que faz com que a cada afirmação de uma corresponda a afirmação da outra, conduz, na verdade, a um envolvimento recíproco". O pensamento de Husserl se dirigia assim para a possibilidade do reencontro entre filosofia e ciência, entre a "essência morfológica" e a "experiência fenomenológica". Por trás destas interpretações, a questão central é a da redução, concernente a distinção entre a atitude natural e a atitude transcendental. Merleau-Ponty diz que Husserl sabia, "desde o início, que de fato elas se entrecruzavam e que todo fato de consciência carrega consigo o transcendental”. A oposição entre a essência e o fato é abandonada na fenomenologia genética por Husserl, pois este sente a necessidade de mostrar a gênese do sentido imanente às coisas. A essência cessa de ser "pura". Merleau-Ponty abandona a investigação a propósito de um saber filosófico puro, pois as essências tornam-se "laços" de significações abertas; estas estão em contato com a experiência e poderão ser refeitas ou desfeitas na história do saber que caminha em direção à verdade (Merleau-Ponty, 1960, p.128-163).

Merleau-Ponty escreve, por isto, que o pensamento intuitivo de Husserl deve ser posto em "movimento", e que, assim acontecendo, a "visão das essências" se transforma em uma fenomenologia da gênese onde o tempo e o ser estarão ligados. Em outras palavras, se a redução ultrapassa a atitude natural, será para reconhecer que este ultrapassamento conserva o mundo inteiro da atitude natural. Para Husserl, a reflexão fenomenológica começa pela descrição da atitude natural e ela nos remete à atitude transcendental. $\mathrm{O}$ problema para Merleau-Ponty está em ver quais são as relações entre estas duas atitudes e, de modo mais particular, como fazer uma fenomenologia do mundo natural ou "a descida ao domínio de nossa arqueologia" para aí pensar a "constituição pré-teorética"; esta é encarregada de fazer-nos compreender os "pré-dados", estes laços de significação em torno dos quais "gravitam" o mundo e o homem, e do qual pode se dizer, indiferentemente, (como Husserl disse Do do corpo) que eles estão sempre para nós “já constituídos” ou que eles não são "nunca completamente constituídos” (Merleau-Ponty, 1960, p.205-219). 
Esta análise dos fundamentos não se faz por dedução ou indução; não se pode dizer que uma é a primeira em relação à outra; elas são inter-necessárias, entrelaçadas, uma não existe sem a outra e Merleau-Ponty as nomeia "camadas profundas" e "camadas superiores". Não podemos mais, então, compreender o transcendental como o campo ideal, como ideação; ele se torna o campo de "toda experiência” da essência e da existência inseparáveis; ele é o campo das "transcendências", realizadas por um sujeito concreto e não por um ego transcendental.

Colocando-nos na perspectiva do constituído, parece que Merleau-Ponty está de acordo com Husserl, quando diz que a reflexão apreende o constituído em sua essência, que ela não pode ser "coincidência”, que ela não está colocada na atitude da constituição operante, mas sim da já operada. De qualquer modo, escreve "bom grado ou mal grado, contra seus planos e conforme sua audácia essencial, Husserl desperta um mundo selvagem e um espírito selvagem (...), articulação e membros do ser que se realiza através do homem” (Merleau-Ponty, 1960, p. 224-228).

Na comunicação, feita em 1959, (Le philosophe et son ombre), ele traça as linhas gerais da nova investigação, que já havia sido iniciada, em direção de uma filosofia da fenomenologia e que fora anunciada na Estrutura do Comportamento. Ela se transformará, com os anos que virão, numa investigação sobre o ser e a verdade considerados do ponto de vista ontológico.

Até aqui nos limitamos a destacar a concepção da fenomenologia de MerleauPonty, que pretendia ser um prolongamento do pensamento impensado, ainda, não explicitado, e à sombra, do próprio pensamento de Husserl.

Assim fazendo, não estaria Merleau-Ponty realizando uma interpretação pessoal, inaugurando deste modo uma outra fenomenologia em relação àquela de Husserl?

Prossigamos nossa investigação por meio da leitura de seus últimos escritos sobre a redução e a constituição. É preciso não esquecer, entretanto, que em Resumo dos Cursos, de 1958-1959, Merleau-Ponty já dizia que a redução se "revela paradoxal" nas constantes démarches do pensamento de Husserl e que ela termina por aporias que vão "recolocar em causa o método da redução". Com efeito, se analisarmos a démarche da fenomenologia genética ela nos conduzirá aos problemas dos prédados compreendidos como a relação entre o corpo próprio (Leib) e o mundo (os outros e as coisas); somos levados, então, a uma gênese mais longínqua: aquela que se refere à constituição destes pré-dados ou "destes materiais brutos" que, graças aos atos da consciência, já pertencem à ordem da constituição ou do plano transcendental, quando deles tomamos consciência.

Estas aporias se erguem no Lebenswelt porque não temos mais que compreender como é possível "pensar um mundo pré-constituído no momento em que ele se constitui", porque o que há é a "inerência de si ao mundo"; e o que devemos fazer é descrever esta experiência integral que nos "conduz a um Ser aberto". Aos olhos de Merleau-Ponty, Husserl interpreta sempre mais esta crença no em-si da atitude natural e da objetividade da ciência, como conduzindo à reflexão sobre o ser, do qual nasce esta crença, e que é a origem da consciência tética que 
põe as coisas como em-si. O Lebenswelt é o pré-dado universal passivo, a fé primitiva no Ser. Aprofundando esta investigação sobre o Ser, anterior a toda posição, anterior a todo juízo e a toda representação, Merleau-Ponty se volta para o Ser Bruto ou Selvagem; não devemos, entretanto, confundir este empreendimento com o de uma metafísica do ser já qualificado, já constituído, pelo pensamento sedimentado da história da filosofia. A filosofia interroga esta fé no ser, ela procura dizer isto que ela ouve em silêncio, procura pôr ao claro a sombra do ser ou o invisível do visível. Entretanto, não devemos pensar que Merleau-Ponty queria substituir o irrefletido pela reflexão, mas antes queria mostrar que eles estão em relação recíproca (Merleau-Ponty, 1964, p. 57).

É nas notas de $O$ Visível e o Invisível, ainda mais do que na redação do manuscrito sobre Interrogação e Intuição da mesma obra, que vemos seu esforço para ultrapassar certos problemas presentes na Fenomenologia da Percepção em relação ao método fenomenológico; estes problemas foram colocados também por Husserl, principalmente na análise intencional dos atos da consciência. MerleauPonty diz que é preciso retornar à intencionalidade operante e latente, interior ao ser. E a redução não é outra coisa que a redescoberta do ser vertical. A crítica dirigida contra a redução eidética é feita várias vezes nesta obra. Assim, nas notas de janeiro de 1959, ele indica que a redução pressupõe a linguagem, necessária para "constituir a consciência constituinte", ou aquilo que ele chamou, na Fenomenologia da Percepção, de Cogito tácito, isto é, uma consciência que está "próxima de si", consciência cuja essência consiste em dar significações. Como se vê, a relação entre essência e linguagem é aqui pressuposta. A essência é, portanto, um conceito "analógico" para falar das coisas. Ora, a doação de sentido coloca uma questão mais profunda que a da constituição ou da relação entre essência e linguagem: é que "as significações são invisíveis", elas nos põem em presença de uma ausência; em outras palavras, este invisível indica que há uma presença dada sob a modalidade de ausência ou de "afastamento" do ser. ${ }^{9}$

Se nós aproximarmos esta afirmação da idéia segundo a qual a articulação do sentido conduz-nos à linguagem, nós compreenderemos que Merleau-Ponty propõe que estes "laços de sentido" sejam procurados a partir da presença do visível no mundo percebido, como o "avesso" ou a outra dimensão deste visível; as significações são o invisível do mundo percebido, e nós sabemos que eles não devem se separar; eles são apreendidos juntos na totalidade do Ser. As "significações não são o invisível absoluto: elas nos fazem ver pelas palavras”.

Vê-se, assim, que para Merleau-Ponty, o Husserl, das últimas horas, havia ultrapassado a dicotomia entre fato e essência, pois a atitude transcendental é complementar da atitude natural, seu fundamento se encontra na crença

\footnotetext{
${ }^{9}$ Merleau-Ponty aproxima este problema do Cogito e ele se auto-critica, pois o Cogito tácito é impensável; é preciso, antes, pensá-lo como cogito falante. Conferir V. Invisível, pp. 225-229-232267. Na nota do V.I. pp. 301-302, a crítica ainda é mais profunda, pois a consciência, por princípio, não pode tudo ver, pois ela é um Cogito encarnado. O que a consciência não vê são suas amarras ao ser.
} 
primordial constitutiva de nossa inerência ao mundo: o corpo (e não mais a consciência) se torna o correlato do mundo que já está aí, o sujeito não é mais um "eu penso" o mundo, mas um "eu posso" aberto ao mundo, um poder motor e ativo que reside no corpo próprio. É assim que a fenomenologia das essências se torna uma fenomenologia da existência, na análise que Merleau-Ponty faz dos escritos de Husserl.

Esta fenomenologia existencial tem seu sentido específico e primeiro como uma analítica da existência. Ora, como o homem é o único existente que pode interrogar sobre o sentido da existência, Merleau-Ponty parte, então, da análise da vida concreta e cotidiana do ser-no-mundo. O homem e o mundo são os dois grandes temas da fenomenologia existencial, temas que conduzem à ontologia.

Justamente porque somos "ser-no-mundo", pensamento encarnado, existência em situação, é preciso tomar distância em relação ao mundo para poder vê-lo; e é precisamente neste sentido que devemos interpretar a redução, como já mostramos anteriormente. A redução não nos separa nem nos retira do mundo; ela necessita que nos afastemos, que nos distanciemos, embora permaneçamos sempre ligados ao mundo. Pela redução, entrevemos este elo entre o homem e o mundo, como um elo intencional que nos permite "conceber o sujeito como transcendência em direção ao mundo".

Parece-nos que esta mesma idéia revem quando Merleau-Ponty afirma que, pela redução, tentamos "fazer aparecer o mundo tal qual ele é, antes de qualquer retorno sobre nós mesmos”, mas, "a ambição de igualar a reflexão à vida irrefletida da consciência”, está destinada ao fracasso, pois há cruzamento entre elas, mas nunca coincidência. Assim, a idéia de que a fenomenologia é uma apreensão original e intuitiva do fenômeno, inspirada pelas exigências das coisas nelas mesmas, será afirmada como impossível.

A pesquisa das origens ou do fundamento, na fenomenologia genética de Husserl, faz com que o tipo de redução seja modificado, assim como se modifica a variação imaginária da fenomenologia estática. A eidética tem uma história, um horizonte último para todo sentido. Se nos colocarmos na perspectiva do objeto constituído, estamos na intencionalidade de ato da fenomenologia estática. Mas se buscamos a compreensão da gênese da constituição, estamos na intencionalidade operante que nos mostrará a unidade homem-mundo.

Através da fenomenologia da existência nós compreendemos a historicidade do ser humano.

Para Merleau-Ponty, esta historicidade só pode se compreender como história "Dichtung", isto é, história-poemática, como já falara Husserl ao dizer que a tarefa da História da Filosofia consistia em compreender esta "Dichtung". Por "história poemática" Merleau-Ponty quer sublinhar o papel da "criação" em história, e indicar que ela é comparável à produção poética, possuindo, entretanto, como característica particular o seguinte: a história é um fazer em comum que sem cessar se faz sob o modo do "Nós", isto é, na coexistência social (MerleauPonty, 1960, p.87). 
Para nós, entretanto, será principalmente por causa do ritmo de sua execução que a história é compatível à poesia. O primeiro ritmo é do entrelaçamento e do entrecruzamento no processo dialético da história visto que os momentos antecedentes se reportam aos seguintes, carregando consigo um ou vários sentidos necessários ao sentido do momento precedente. Por aí se compreende que os sentidos presentes na história se superpõem, prolongando-se. O segundo ritmo é o "hiatus" pelo qual se exprime ao mesmo tempo a continuidade, a relação, mas também a distância que separa duas coisas que se afastam. É graças a este ritmo que se torna possível a percepção histórica, isto é, a possibilidade de instituir-se uma articulação do campo perceptivo que nos permite ver sem coincidir, mas de tal forma que o afastamento não faça ou não permita que a articulação desapareça introduzindo-se, se isto ocorrer, o esquecimento da tradição. Finalmente, aquilo que se rejeita, mas que, justamente pela sua rejeição, indica a nova força que brota na história e que se liga intimamente às situações que lhe precedem, mas que tivemos que abandonar face ao progresso da história que aparece no seu brotar frutificante.

Merleau-Ponty não cessou jamais de questionar, de "cavar" em maior profundidade o que é a percepção originária. Da Fenomenologia da Percepção ao Visível e Invisível às modificações, se assim podemos nos expressar, giraram em torno de dois eixos fundamentais. O primeiro que consistiu na sua autocrítica, de que o Cogito de que falou na Fenomenologia da Percepção, estava preso ainda aos princípios de uma concepção da Filosofia da Consciência Transparente, apesar de ter realçado a importância do corpo próprio e do anonimato fundamental de existência que se entrecruzava na formação do Ego e na coexistência social. O segundo é a pesquisa em direção a uma ontologia do Sensível, onde o Ser é "qualificado" como amorfo ou polimorfo, mas cujo "elemento", a Carne, se apresenta como força instituinte na Carne do Mundo, no Ser visto, no Sensível, na Carne do Homem, na Carne da História concreta.

Se nós o acompanharmos neste caminho da interrogação de uma Ontologia do Sensível, todos os Sensíveis se encontrarão finalmente reunidos no Horizonte Total do Ser Bruto ou do Ser Selvagem, dito polimorfo. É deste Ser Bruto que são pré-erguidas todas as dimensões e será para explicitar este poder de "pregnância" ou de "brotar de uma forma" que Merleau-Ponty falará de Historicidade Vertical. Ora, o que torna possível esta Verticalidade é o negativo ou o invisível, porque, diz-nos ele: "o visível é pregnante de Invisível" e esta pregnância é poder de fecundação e possibilidade objetiva de fazer brotar, fazer nascer, de criar. É neste sentido que se deve entender a "instituição originária" que nos permite dizer que a forma é "isto que aconteceu a si mesma e que por seus próprios meios se coloca" (em postura de ser). Esta instituição originária é o princípio em virtude do qual há o "surgir imotivado", há instituição e não subsunção (Merleau-Ponty, 1964, p.262).

Por conseguinte, é graças à Historicidade Vertical que o Ser se põe na postura de estar de pé, isto é, que se produz a colocação em posição ou em "Station" do "há o Ser". É graças à Historicidade Vertical que o "há”, “existe”, é posto na presença de maneira durável. A idéia de Verticalidade se liga, portanto, para Merleau- 
Ponty, à existência e esta não se reduz ao Ser do homem. Diz-nos ele que "está de pé a existência que está ameaçada pela força da gravidade dos corpos”. É por isto que se pode dizer que o corpo humano e o mundo são duas verticalidades. Com efeito, Merleau-Ponty (1964, p.263) escreve que "o corpo se põe de pé diante do mundo e o mundo se põe de pé diante do homem, e há entre ambos uma relação de entrelaçamento". Entre estes dois Seres Verticais há uma superfície de contato que é a Carne Geral ou a Visibilidade.

Vê-se, portanto, que a Historicidade está estreitamente ligada à instituição, ou antes, que instituir é específico à historicidade para Merleau-Ponty. É graças a este conceito de instituição que é possível apreender-se uma certa estabilidade no movimento do Ser, na natureza, na história concreta e no ser do homem. É ainda graças ao conceito de instituição que se pode reparar a "espontaneidade cumulativa" e a "sedimentação ativa". A historicidade explicita esta movência institucional ao seio da "história cumulativa" e de uma "espontaneidade ensinante" (Merleau-Ponty, 1964, p.324).

A filosofia vai buscar a explicação do Ser Bruto ou Selvagem que se encontra aquém do Ser já instituído em sua essência em seu "tecido da experiência, desta carne do tempo". A linguagem que busca explicitar este sentido do Ser Bruto ou Selvagem, se encontra, na verdade, numa certa "coincidência longínqua" com o Ser, mas, como justifica Merleau-Ponty, a palavra é possível porque "nós estamos no Ser", ou seja, a linguagem é este "nó do Logos ao Ser, pois a filosofia é a reconversão do silêncio e da fala um no outro". O acesso ao Ser é intra-ontológico, o Homem e o mundo estão entrelaçados no entrelaçamento intercorporal com os outros. A partir deste nexo carnal, Merleau-Ponty abre toda uma perspectiva de análise com Freud onde a questão da sexualidade, do desejo, da carícia erótica tem o seu lugar, bem como a sua sublimação, a idealidade da carne na expressão da criação artística ou imigração, modificação da carne em expressão, linguagem segunda ou, como diz o próprio Merleau-Ponty, "reversibilidade da palavra e da carne que se manifesta por uma existência quase carnal da idéia como por uma sublimação da carne”. A interrogação filosófica coloca em questão a própria questão, ou seja, ela se interroga o que é "significação Ser, o que é o Ser da significação e o lugar da significação no Ser” (Merleau-Ponty, 1964, p.203).

Merleau-Ponty chama o Visível de Carne, generalidade do Sensível em Si, anonimato inato de mim mesmo. Esta noção de Carne não se confunde com a matéria, a substância ou com o espírito ao qual ela está unida. Ela é "um elemento, no sentido em que os gregos empregaram este conceito para falar da água, do ar, da terra e do fogo, isto é, no sentido de uma coisa geral, a meio-caminho do indivíduo espaçotemporal e da idéia (...). A carne neste sentido é elemento do Ser”. E Ser aqui é dito "Ser Bruto", "Selvagem” (Merleau-Ponty, 1964, p.220).

Conforme ilustra Canguilhem, o termo "selvagem" nos remete a nostalgia da autenticidade expressa pelo desejo de retorno ao arcaísmo e ao naturalismo da vida ou das comunidades primitivas. Poder-se-ia dizer que em filosofia "Ser Selvagem" quer significar, para Merleau-Ponty, o retorno à aurora da filosofia como fonte inspiradora deste contato inocente e espantoso que nos abre as portas para o 
maravilhamento do que há, do que existe, do que já está aí, do Ser que se faz Visível, que possibilita a instituição e a emergência dos entes, e que nos incita a indagar: por que há o ser e não antes o Nada?

Trata-se da nostalgia e do retorno, ou antes, da reapropriação no presente vivido de uma nova relação entre Logos e Verdade entre Espírito e Verdade, ou como dizia Merleau-Ponty, o que ele buscava nesta obra que ficou inacabada era retomar a questão sobre a "Origem da Verdade".

A noção de carne como elemento no sentido grego inicial, não se confunde, pois com o tecido muscular animal ou humano oposto ao esqueleto ósseo. Não é nem mesmo colocada em oposição ao espírito quando se diz, por exemplo, "os pecados da carne", "a carne é fraca", numa perspectiva de concupiscência e de sensualismo. Do ponto de vista religioso se diz "o Verbo se fez carne", encarnou na natureza humana, tem um corpo e um espírito que é do próprio Deus. Todas estas expressões supõem o dualismo corpo-espírito, corpo-alma espiritual, aos quais a filosofia sempre procurou caminhos para justificar a sua união. Ora, o que Merleau-Ponty fez, durante toda a sua vida, foi refutar este dualismo e buscar novas formas de pensar a unidade.

Merleau-Ponty explica: "Ser carnal (se entende) como ser das profundezas, que tem diversas faces, é ser de latência e presentificação de uma certa ausência, é um protótipo do Ser, do qual o nosso corpo, o sentido e o sensível, é uma variante remarcável”. O paradoxo de nosso corpo próprio em sua vida é que ele é corpo sensível e o corpo que sente, ele é, ao mesmo tempo, corpo objetivo (tal como a ciência o aborda) e corpo fenomenal (tal como a fenomenologia explicita esta noção de fenômeno - Ser que se mostra de si mesmo no seu aparecer). Mas este paradoxo é ainda mais complexo, pois este corpo que sente e é sensível é também pensante. Assim, ser carnal é refletir acerca desse Ser Paradoxal em sua unidade, tal como se dá nesta variante humana. Mas esta variante humana pertence, como variante, a um paradoxo maior com o qual ela se enlaça, pois ele é Ser-no-mundo e o "mundo é a carne universal".

A carne é, assim, o elemento visível universal, Princípio Universal, "inauguração do onde e do quando, possibilidade e exigência do fato, isto que faz com que o fato seja fato". Chegar ao princípio que permite compreender o Visível em sua universalidade, ou seja, que Natureza e vida são entrelaçadas, pelo mesmo elemento carnal, como uma infra-estrutura, isto não é suficiente para MerleauPonty. E por quê?

Por que se entre eles há uma unidade é necessário ainda explicitar a diferença. A vida humana, ou a carne do corpo humano não se comporta igualmente como a carne da natureza. Só ela pode se tocar e se ver e nisto se apreender como sujeito pessoal e não como objeto. Esta abertura a si-mesmo, este narcisismo do Ego, não é fechamento em si mesmo, pois ele é o indicativo de que este Ser Carnal humano é essencialmente abertura a si, ao outro, ao mundo e a transcendência. $\mathrm{O}$ Visível é "dimensionalidade do Ser, um universal" e nele se apresenta sempre um "outro lado" nele ancorado. Esse "outro lado" pode ser a Natureza como o outro lado do homem. Natureza aqui não se entende no sentido do naturalismo, nem de uma natureza em si da escolástica, mas do entrelaçamento "homem-animalidade". 
Concluindo, podemos afirmar que a fenomenologia existencial de MerleauPonty procurou compreender o outro, na relação a meu eu, numa dimensão de sua experiência vivida concretamente em seu contexto histórico-social e psicológico. Ele examinou esta temática fazendo um confronto crítico com a psicologia, a biologia, a psicanálise e o marxismo francês e soviético, da sua época. O outro é abordado não como um objeto externo, mas como outrem, como um outro eu que é um ser pessoal.

É através de meu corpo próprio, com sua sensibilidade e mobilidade, que apreendo o outro eu no horizonte de seu mundo primordial; é através do corpo próprio como poder, como um "eu posso", que ajo no mundo de uma certa maneira, adquirindo hábitos e modos do meu ser. Só então será possível entender a constituição do mundo comum, do mundo partilhado com os outros, do mundo histórico-social da intersubjetividade em ação. Depreende-se daí que eu não vivo diretamente o corpo do outro como um corpo próprio, mas sim como um corpo que se dá na apercepção como um corpo semelhante ao meu.

O corpo do outro eu se mostra situado diante de mim e pode fornecer um fundamento motivacional para a apreensão analógica do corpo que lá está como um corpo próprio. Não basta, entretanto, dar-se a apercepção do outro como tal. Faz-se necessário compreendê-lo e isto requer a palavra, ou seja, o campo de abertura de um horizonte de compreensão e interpretação pela mediação da linguagem.

Convém observar que Merleau-Ponty critica todas as formas de empirismo, de mecanicismo e de idealismo por conceberem o homem de modo dualista, separando sujeito e objeto; ele insiste na superação da dicotomia alma e corpo, consciência e mundo, consciência e inconsciente no estudo do cogito, pois o fenômeno humano se mostra, em sua vida vivida na cotidianeidade, na unidade, nos paradoxos e ambigüidades que ele apresenta na descrição da percepção do corpo próprio. O sujeito, enquanto um eu que vive só, se auto-percebe como corpo no mundo (no seu sentido dado pela biologia) na medida em que percebe o corpo do outro como o de um sujeito próprio, isto é, como um corpo subjetivado. É porque sou capaz de perceber o outro como tal, que sou capaz de me auto-perceber como um sujeito no mundo que pode ser percebido por um outro sujeito. Emerge, pois, a consciência de si próprio graças a esta experiência do outro como um outrem. Assim, entre as coisas por mim vividas, nada impede que eu me dirija para o outro percebendo-o como outro, percebendo-o na sua conduta.

A relação interpessoal originária, fundante, se dá sob a forma da amizade, raiz de toda comunidade e sociedade. No entanto, Merleau-Ponty não deixa de mostrar que ela pode se dar sob a forma não fundante da não amizade, tal como a agressividade, o ódio, a violência ou outros elementos destrutivos de caráter conflitante na relação interpessoal.

Mas a simples percepção do outro em seu corpo não basta para o entendimento do outro como seu corpo próprio; é necessário que o seu comportamento expressivo seja de certo modo compreendido. A vida intersubjetiva pressupõe a compreensão, a linguagem que nos permite viver o mundo enquanto uma comunidade de pessoas. Esta vivência intersubjetiva é expressão do eu 
enquanto pólo de afeição e de ações, de modos autênticos e inautênticos de se constituir a vida pessoal em comunidade.

Se acompanharmos as idéias de Merleau-Ponty, em sua obra "Fenomenologia da Percepção", em seus artigos publicados do Boletim de Psicologia da França, em seus cursos ministrados na Universidade da Sorbonne sobre as questões da relação com o outro e a psicologia, veremos que o seu entendimento do comportamento humano não se faz sob a égide da narrativa behaviorista. $\mathrm{O}$ comportamento emerge como uma Gestalt, um Todo Estruturado Estruturante, onde a dimensão externa e interna do fenômeno estão entrelaçadas de modo indissociável. Tal comportamento emerge num campo fenomenal, no qual corpo (o meu e o do outro) e mundo são, percebidos como numa interfusão que precisa ser descrita, explorada, aclarada, compreendida e interpretada.

Merleau-Ponty assim se expressa: "há um homem efetivo, real, concreto, que não se limita a possuir consciência ou corpo, ou a enfrentar-se com a realidade externa, mas sim que é consciência-corpo unidos". O ato de compreender esta existência situada, engajada, é um ato que se dá "como reflexão sobre um irrefletido" que a reflexão não reabsorve de fato nem de direito (Fenomenologia da Percepção, pp. 52-53). Daí se depreende que o pensamento objetivo se volta e se nutre da facticidade do irrefletido e realiza o trabalho de explicitação da vida da consciência irrefletida. Assim se expressa Merleu-Ponty: "se refletir é buscar o originário, e isto pelo qual o resto pode ser pensado, a reflexão não pode fechar-se no pensamento objetivo, pois ela deve justamente pensar os atos de tematização do pensamento objetivo e restituí-lo em seu contexto" (Fenomenologia da Percepção, p. 334).

Gostaria, ainda, de mencionar que a subjetividade, nas teorias da organização, é um tema recente na administração e na teoria do poder. É a subjetividade como experiência vivida em contexto organizacional que envolve a intersubjetividade, a expressão, a participação, as emoções, em suma, o sujeito capaz de fazer escolhas, de tomar decisões, de examinar a dimensão política de suas ações, as estratégias ou as boas razões para agir segundo o seu modo de pensar.

Concluindo, podemos dizer que, para Merleau-Ponty, a presença do outro homem não se dá sob a forma de presença de uma consciência à outra consciência. Ela se mostra a nós como corpo animado de um comportamento visível, pela sua fala, pela sua ação, pela sua emoção, pelos seus sentimentos, pela sua intenção que se mostra em seus atos. Nós podemos compreendê-lo. Isto implica em mútua presença, mútua comunicação, em coexistência, em intersubjetividade ou, como se expressa Husserl, em "experiência da compreensão da vida do mundo espiritual". Por isto as pessoas valem mais do que as coisas, valem por si mesmas e não pela posição social que ocupam. Essa dimensão valorativa da relação interpessoal nos coloca na dimensão ética onde valor, liberdade, respeito e dignidade são essenciais. Viver é conviver. Não é possuir tão-somente células vivas, ter um organismo biológico, estruturas neuro-fisiológicas e químicas em funcionamento. Na vivência humana há outros elementos, tais como o relacionamento interpessoal, o compartilhamento de idéias, de emoções e sentimentos. Isto Husserl chamava de vida espiritual. 


\section{Referências Bibliográficas}

Biemel, W. (1959). Les phases décisives dans le développement de la philosophie de Husserl, Cahiers de Royaumont-Husserl. Paris: Éditions du Minuit.

Capalbo, C. (2004). A filosofia de Maurice Merleau-Ponty. Historicidade e Ontologia. Londrina: Edições Humanidades.

De Waelhens, A. (1959). Sur l'idée de phénoménologie, Cahiers de RoyaumontHusserl. Paris, Editions du Minuit.

Fink, E. (1952). Problèmes actuels de la phénoménologie. Paris: Desclée De Brouwer.

Husserl. E. (1950). Idées directrices pour une phénoménologie. Paris: Gallimard.

Husserl. E. (1953). Méditations Cartésiennes. Paris: Librairie Philosophique J. Vrin.

Husserl. E. (1957). Logique formelle et logique transcendantale. Essai d'une critique de la raison logique. Paris: PUF.

Husserl. E. (1961). La Crisi delle Scienze Europee e la fenomenologia transcendentale. Milano: Il Saggiatore.

Husserl. E. (1964). Leçons pour une phénoménologie de la conscience intime du temps. Paris: PUF.

Husserl. E. (1970). Expérience et Jugement. Recherches en vue d'une généalogie de la logique. Paris: PUF.

Ingarden, R. (1959). Le problème de la constitution et le sens de la reflexion constitutive, Cahiers de Royaumont-Husserl. Paris: Éditions du Minuit.

Merleau-Ponty, M. (1945). Phénoménologie de la Perception. Paris: Gallimard.

Merleau-Ponty, M. (1960). Signes. Paris: Gallimard.

Merleau-Ponty, M. (1963). La Structure du Comportement. Paris: PUF.

Merleau-Ponty, M. (1964). Le Visible et l'Invisible. Suivi de notes de travail. Paris: Gallimard.

Merleau-Ponty, M. (1968). Résumés des Cours (Collège de France, 1952-1960). Paris: Gallimard.

Ricoeur, P. (1950). Nota 4, In Edmund Husserl, Idées directrices pour une phénoménologie. Paris: Gallimard.

Saraiva, M. (1970). L’imagination selon Husserl. Den Haag: Martinus Nijhoff. 
Sokolowski, R. (1970). The formation of Husserl's concept of constitution. The Hague: Martinus Nijhoff.

\title{
Van Breda, H.L. (1962). Merleau-Ponty et les Archives Husserl à Louvain, Revue de Métaphysique et de Morale. Vol.4, p. 410-430.
}

\begin{abstract}
The phenomenology of Merleau-Ponty follows, in his way, the thought found in "Krisis", the unfinished work of Husserl. He criticizes the transcendental theory and the reduction method proposed by Husserl, because he thinks that one has to confide to the philosophy of existence and of subjectivity, in his condition of being situated in the world of life. The most important for the subject is the search for the sense for his life and this, transporting to his limit, clear us about what is the nature, the history, the world and the being. Merleau-Ponty existential analytic about the experience of other and of subjectivity is made from his being-in-the-world, that is to say, in the historical, social and psychological context.
\end{abstract}

Key-Words: Phenomenology, Subjectivity, Existence, Historicity, World of Life.

Resumen: La Fenomenología de Merleau-Ponty sigue, a su modo, el pensamiento encontrado en la obra inacabada de Husserl "Krisis". Él critica la teoria transcendental y el método de la reducción propuestos por Husserl, por creer que se debe atener a la filosofía de la existencia y de la subjetividad, en su condición de estar situado en el mundo de la vida. Lo más importante para el sujeto consiste en buscar un sentido para su vida, y eso, llevado a su término, nos esclarece sobre lo que es la naturaleza, la historia, el mundo y el ser. El análisis existencial de Merleau-Ponty sobre la experiencia del otro y de la subjetividad, se hace a partir de su ser-en-el-mundo, o sea, en el contexto histórico, social y sicológico.

Palabras-clave: Fenomenologia, Subjetividad, Existencia, Historicidad, Mundo de la Vida.

Creusa Capalbo é Doutora em Filosofia, Professora Titular na Universidade Federal do Rio de Janeiro e Professora Adjunta na Universidade Estadual do Rio de Janeiro. Realizou Pós-Doutorado na Universidade Francesa de Estrasburgo.

Recebido em 15.04.07 